\title{
Nas conversas e nos silêncios: memórias inundadas por Belo Monte
}

In Conversations and Silences: Memories Flooded by Belo Monte

En conversaciones y silencios: recuerdos inundados por Belo Monte

Camila Aranha (Universidade Federal do Estado do Rio de Janeiro, Brasil)*

https://doi.org/10.22409/poiesis.v22i37.47239

\begin{abstract}
RESUMO: As ruínas de Santo Antônio e suas memórias inundadas revelam o processo de perda do espaço afetivo. A hidrelétrica de Belo Monte construída no Pará, em funcionamento desde 2016, é um símbolo da "modernidade" da Amazônia. Neste projeto nacional, as populações mais vulneráveis foram excluídas. Em busca por memórias georreferenciadas na região e na resistência social, realizei uma investigação sobre a história da agrovila Santo Antônio narrada através das memórias das famílias expulsas pela barragem, tratadas conceitualmente como memórias inundadas. Nesta extinta comunidade, moraram cerca de 60 famílias. Encontrei antigos moradores que compartilharam suas reconstruções simbólicas sobre o vivido naquele espaço.
\end{abstract}

PALAVRAS-CHAVE: memória afetiva; vila Santo Antônio; hidrelétrica de Belo Monte

* Camila do Socorro Aranha dos Reis é professora de Arte da Rede estadual de Educação do Pará (SEDUC-PA) na cidade de Salinópolis e doutoranda em Memória Social pelo Programa de Pós-Graduação em Memória Social da Universidade Federal do Estado do Rio de Janeiro (UNIRIO). Orcid: http://orcid.org/0000-0002-4434-8362. E-mail: cami.aranha@gmail.com. 
ABSTRACT: The ruins of Santo Antônio and their flooded memories reveal the process of loss of affective space. The Belo Monte dam built in Pará state, working since 2016, is a symbol of the "modernity" of the Amazon. In this national project, the most vulnerable people have been excluded. In search of georeferenced memories in the region and social resistance, I realized an investigation about the history of the Santo Antônio small village narrated through the memories of the families expelled by the dam. The memories of these families were treated conceptually as flooded memories. In this extinguished community, around 60 families have lived. I found former villagers that shared their symbolical reconstruction about the lived in that space.

KEYWORDS: affective memory; Santo Antônio village; Belo Monte dam

RESUMEN: Las ruinas de Santo Antônio y sus recuerdos inundados revelan el proceso de pérdida del espacio afectivo. La central hidroeléctrica de Belo Monte construida en Pará, en funcionamiento desde 2016, es un símbolo de la "modernidad" de la Amazonia brasileña. En este proyecto nacional, se excluyeron las poblaciones más vulnerables. En busca de recuerdos georreferenciados en la región y en resistencia social, realicé una investigación acerca de la historia del pueblo de Santo Antônio contada a través de los recuerdos de las familias expulsadas por la represa, tratados aquí como recuerdos inundados. En este extinto pueblo, vivían unas 60 familias. Conocí a antiguos residentes que compartieron sus reconstrucciones simbólicas sobre lo que se vivía en ese espacio.

PALABRAS CLAVE: memoria afectiva; pueblo de Santo Antônio; represa de hidroeléctrica Belo Monte.

Citação recomendada:

ARANHA, Camila. Nas conversas e nos silêncios: memórias inundadas por Belo Monte. Revista Poiésis, Niterói, v. 22, n. 37, p. 115-136, jan./jun. 2021.

[https://doi.org/10.22409/poiesis.v22i37.47239]

(cc) BY-NC-ND

Este documento é distribuído nos termos da licença Creative Commons Atribuição-NãoComercial 4.0 Internacional (CC-BY-NC) (c) 2021 Camila Aranha

Camila Aranha, Nas conversas e nos silêncios: memórias inundadas por Belo Monte. 


\section{Nas conversas e nos silêncios: memórias inundadas por Belo Monte}

O ponto de partida

Parte da história da agrovila Santo Antônio foi "escrita" durante o plano de colonização da Amazônia, arquitetado pelo então governo militar na década de 1970 . Este período marca o momento de encontro do rio Xingu com "rios modernos" estradas abertas na mata fechada, dentre essas, a rodovia Transamazônica ${ }^{1}$, que fragmentou importantes territórios indígenas. Ironicamente, 40 anos depois, a pequena vila cede espaço a outro projeto de "modernização": a Usina Hidrelétrica
(UHE) de Belo Monte. No instante em que fincaram as primeiras placas com inscrições "Propriedade particular - NÃO ENTRE" se iniciou o deslocamento compulsório de cerca de 60 famílias em 2012. Este vilarejo foi uma das primeiras comunidades expulsas pela barragem. $\mathrm{Na}$ busca por compreender este lugar a partir das memórias de antigos moradores, me deparo com as reconstruções simbólicas do vivido e a partir delas apresento a cartografia dos afetos de Santo Antônio. 
O território amazônico é um espaço de resistência em si ao se ressignificar constantemente perante à colonialidade, onde se tecem diferentes construções simbólicas do viver. Em outras palavras, são lugares afetivos, identidades e memórias. A vila Santo Antônio fazia parte do município de Vitória do Xingu, no Pará, localizada precisamente entre as margens do rio Xingu e o chamado "quilômetro 50" da Transamazônica. Suas famílias foram desterritorializadas para transformar a comunidade em estacionamento de caminhões, remanescendo hoje reminiscências de quem recorda.

Ao cartografar as memórias de Santo Antônio, encontro imagens de distintas naturezas definidas ao longo das reflexões como imagens de resistência, por resistirem ao tempo através das memórias das famílias entrevistadas e também por, em alguns casos, contribuir para a resistência social de quem recorda o passado e elabora severas críticas ao presente, opondo-se ao projeto de "modernidade" excludente e invisibilizador. A essas imagens associo as imagéticas presentes nas lembranças e reminiscências individuais, aqui tratadas como memórias inunda- $d a s^{2}$, por rememorar paisagens perdidas do rio Xingu (REIS, 2016). Nesse sentido, entendo a cartografia como um mapa aberto, "conectável em todas as suas dimensões, desmontável, reversível, suscetível de receber modificações constantemente" (DELEUZE; GUATTARI, 1995, p. 30).

Esta pesquisa parte do meu próprio deslocamento pela região nas incursões em campo em busca das famílias mais antigas da vila. Apresento uma série de fotografias deste processo de investigação com o intuito de as conectar com os fios de memórias coletadas por meio de entrevistas feitas entre os anos de 2015 e 2016. Essas imagens situam o leitor em parte dos percursos traçados e almejam materializar possíveis reminiscências deste lugar de memória (NORA, 1993). Objetivo analisar as relações entre memória e território, visibilizando assim as histórias das populações expulsas pela hidrelétrica de Belo Monte, motivada pelas palavras de Hal Foster (1996, p. 20) na seguinte reflexão: "esta maneira horizontal de trabalhar demanda que os artistas e críticos estejam familiarizados não somente com a estrutura de cada cultura 
de forma suficiente para mapeá-la, mas também com sua história de forma suficiente para narrá-la". Embarquemos neste processo.

\section{Da terra natal para as terras estrangeiras}

Nos caminhos que se abrem, o rio Xingu é o guia onde as relações de vida acontecem e afluem memórias coletivas de comunidades ribeirinhas, pescadores, extrativistas, dentre outras. Para quem se estabeleceu distante do rio, à beira da estrada e ao entorno dela, os vínculos sociais se desenham e transitam por diferentes modos de vidas: são agricultores, comerciantes, pequenos produtores de cacau e arroz. Estas duas realidades não são opostas, elas coexistem e eram presentes na vila de Santo Antônio.

A ocupação deste solo comum se intensificou na década de 1970 com a abertura da rodovia Transamazônica e o incentivo do governo militar para a imigração. Em sua maioria, foram os nordestinos fugindo da seca que chegaram até a Amazônia. Naquele tempo, o acesso por terra facilitou a apropriação de um espaço des- conhecido para quem era de fora, acelerou também o desmatamento e loteamentos às margens das estradas abertas. O status de agrovila vem com a Emater como chamam a Empresa de Assistência Técnica e Extensão Rural do Estado do Pará -, responsável pela reorganização territorial daquele perímetro da Transamazônica, reunindo famílias que viviam próximas, mas dispersas, e agregando novas famílias de imigrantes.

A agrovila Santo Antônio ganhou este nome por causa de um igarapé homônimo vizinho, comentou Pedro ${ }^{3}$ em nossa primeira conversa. Ele era um dos moradores mais antigos e o último deixar a comunidade no primeiro mês de 2013. Quando o conheci em 2015, ele morava em uma pequena casa onde havia uma mercearia e um bar, na agrovila D'Vinci, também às margens da Transamazônica, mais próxima da cidade de Altamira. 


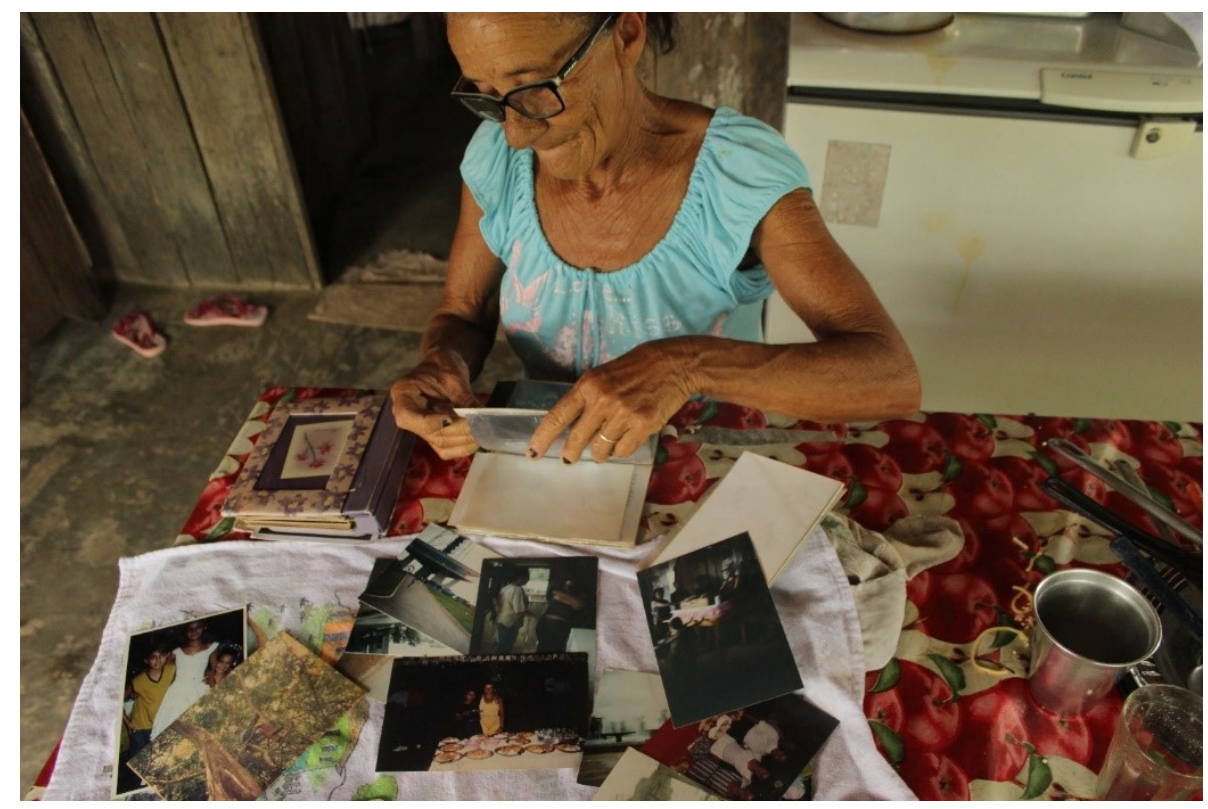

Fig. 1 - Maria e seus álbuns de fotografias de Santo Antônio, 2016.

(Fonte: Acervo da autora.) 
O meu desejo por investigar a história e a memória deste lugar se inicia com o último festejo de Santo Antônio, padroeiro da vila, em 2012, quando a comunidade ainda estava presente. Era 13 de junho, eu chegava cansada de uma viagem de quase 24 horas de Belém, a capital do estado, a Santo Antônio, percorrendo aproximadamente 800 quilômetros de estrada. Na época, grande parte da Transamazônica não tinha asfalto. A festa de Santo Antônio fazia parte da programação de um evento chamado "Xingu+23", organizado pelo o movimento social Xingu Vivo para Sempre. Passei alguns dias hospedada no vilarejo.

Dois anos depois, quando a vila remanescia como estacionamento, reencontrei José. A primeira vez que eu o vi, ele usava um chapéu de vaqueiro e um sapato elegante de couro com bico fino, comum na redondeza de Altamira, o famoso estilo cowboy. Mesmo observando-o à distância, senti o espírito de liderança que carregava consigo. Não por acaso, ele foi presidente da Associação de Moradores da Agrovila Santo Antônio durante anos.
$\mathrm{Na}$ primeira oportunidade de conversar com José, ele carregava consigo o papel da indenização de sua ilha no valor de R\$ 3.000,00 (três mil reais). Mesmo não sabendo ler as palavras escritas e nem as interpretar, apontava o dedo em direção aos números, estes últimos mais familiares. Ao me mostrar o papel com as tabelas de valores das benfeitorias passíveis de indenização, me impressionou a quantia tão baixa dada a sua fonte de sustento, o que em tese tem um preço de mercado. Existia na fala de José também uma atenção ao cultivado em seu quintal como fonte de afeto e de um valor imensurável para si.

As conversas com José revelaram subjetividades consolidadas por imigrantes, como ele, no eixo TransXingu ${ }^{4}$, enfatizando com certa insistência as memórias dos tempos de luta por sobrevivência. De certo modo, uma resistência de viver e cultivar um pedaço de terra. A vila Santo Antônio abrigava famílias de imigrantes: alguns procuravam um lote para produzir sua própria subsistência enquanto outros buscavam aportar em uma beira de rio e pescar. Era um privilégio de viver em 
uma das margens do rio Xingu, com sua fartura de pescado.

A história da agrovila Santo Antônio começa antes mesmo da fundação da vila. Ela remete a um tempo anterior, da partida da terra natal para as terras estrangeiras. É José quem norteia esta reflexão e assim diz:

Existia um projeto na época. Desse projeto chegou a fofoca lá - no estado do Espírito Santo - que aqui na Amazônia Legal existia uma projeto de "terra sem homens para homens sem-terra". E foi isso que fez a gente vir pra cá, sabe? E daí, eu vim nessa fofoca, né? E eu imaginava que como eu me criei dentro da cidade, na roça de fazenda, que não tinha mata, né?... Eu tinha muita ansiedade para conhecer mato assim... Na verdade, eu fui para dentro da mata quando eu cheguei aqui. Aí eu me misturei com os bichos, sabe? (Entrevista gravada em áudio, Altamira, 2015)

As imagens idealizadas sobre a Amazônia se esfacelaram no momento em que a realidade apresentava desenhos completamente diferentes, nunca antes visto. Nas palavras de José: "chegando aqui ${ }_{\perp}$ eu conheci a história bem diferente". Ele rememora:

Daí a minha mãe e a minha família disseram:

"- Mas meu filho, tu vai pra lá, para essa Amazônia, pra esse lugar que é só índio?". Eu falei: "— Gente, lá não só tem índio, lá tem gente também!". Na nossa mente, o índio era um bicho. Na nossa mente o índio é um bicho e isso ainda passa na cabeça das pessoas lá fora. (Entrevista gravada em áudio, Altamira, 2015)

$\mathrm{Na}$ qualidade de um dos guardiões da memória da vila, José foi fundamental para a reconstituição de parte da memória coletiva das famílias que remanesciam na beira da estrada e do rio antes da hidrelétrica. Ele sente as reminiscências do tempo-passado existentes nas ruínasrizomas do que restou da comunidade de Santo Antônio. Ao andar pelas ruínas da agrovila, José aponta para a mangueira que plantou, integrante de seu quintal. Ela permanecia no mesmo local ${ }^{5}$. 


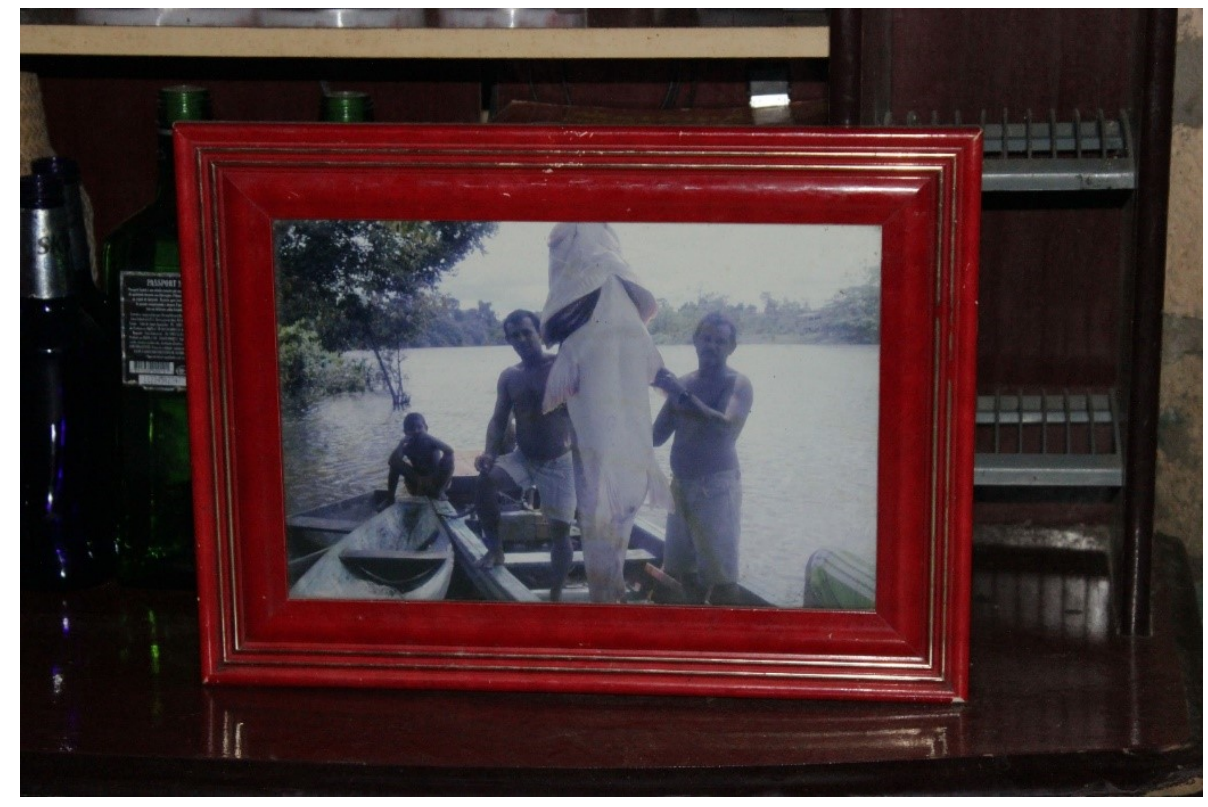

Fig. 2 - As lembranças que guarda da vila, 2016.

(Fonte: Acervo da autora.) 
Quando a vila começava a se desintegrar fisicamente, se consolidando em um tipo de arquitetura da destruição, o que foi abandonado se tornou uma espécie de ruína. Apesar da promessa de reassentar todos os moradores juntos em outro local, isto nunca aconteceu. Com a ruptura dos laços comunitários e a dispersão na região entre os municípios vizinhos, essas famílias foram obrigadas a ressignificar seus próprios modos de vida e suas memórias sobre o lugar vivido. Alguns negaram as novas perspectivas e a readaptação aos novos espaços, resistindo às transformações impostas. A perda também se configura na privação do contato com as paisagens habituais e na eliminação de seus elementos. Perde-se a sonoridade, o cheiro, a textura, a cor e outros pontos fundamentais na recordação. O contato com o familiar é um impulsionador de recordações e não se tem como falar de lugar sem falar de memória, entendendo que "ao perdermos uma paisagem sonora sempre poderemos evocá-la através de sons ou na conversa com testemunhas que a viveram" (BOSI, 1994, p. 447). As antigas famílias da vila são testemunhas das histórias do tempo presente da Amazônia.

\section{As ruínas de Santo Antônio}

"Para mim, o negócio mais péssimo que teve foi essa barragem, porque me tiraram do que era meu depois de 42 anos. Trabalhei tanto, lutei tanto, construí a comunidade, trabalhei em tudo e tive que sair sem direito a nada!" Pedro, Agrovila D'Vinci, 2015

Quando perguntei a Pedro o que lembrava da vila, ele respondeu rápido: "Nada!". Foi no ato de negar as lembranças que elas surgiram forte na memória deste ancião. A partir da negação do passado, ele narrou a criação da agrovila, se colocando como um dos principais protagonistas dessa história:

- (...) eu não gosto nem de lembrar porque é só para ter raiva e sofrer desgosto. 0 que eu fiz? Criei tudo lá. Arrumei o lote [terra] no 46 [quilômetro, refere-se à localização] em [19]73. Lá eu fiz uma igreja, depois me pagaram. Com dois anos a comunidade me pagou, só que quando ela me pagou o dinheiro dava só para comprar uma tábua, porque naquele tempo a inflação era que nem... Fiz o campo [cemitério]. A sede primeiro. Fizemos a sede primeiro, foi feita de paxiúba [palmeira] e [árvore de] açaí e coberta de palha. A segunda foi

Camila Aranha, Nas conversas e nos silêncios: memórias inundadas por Belo Monte. 
feita tapada de bambu e coberta de cavaco

[lasca de lenha]. A terceira vez foi tapada de tábua e coberta de telha. Aí fiz o campo. (...) Depois a gente fez o cemitério porque nenhum teve coragem. (Entrevista gravada em áudio, 2016)

As ruínas se materializam como "um mundo em vias de desaparecimento", esclarece Bruno Latour (2013, p. 40). Elas desvelam memórias, "evocam a passagem do tempo - em alguns casos, como resquícios da falência de projetos modernizadores, utópicos e civilizatórios" (DALCOL, 2015, p. 54). Enquanto resquícios do que existiu, a agrovila Santo Antônio paradoxalmente surge como parte do projeto militar de colonização da Amazônia e falece por outro plano de modernização neocolonialista.

As ruínas de Santo Antônio não se corporificam como restos de construções urbanas, onde o peso do concreto se faz presente. Ao contrário, elas estão mais próximas da natureza e poucas foram deixadas porque muitas famílias reaproveitaram boa parte desses materiais, deslocando-os para novos espaços. Eram tábuas de madeira, ripas de paxiúba (uma espécie de palmeira nativa da Amazônia) e restos de construções "rústicas" se hibridizando com o mato que as consome. Elas resistem ao esquecimento porque permanecem demarcando um território do que foi e restou até hoje, alimentando as memórias de quem já morou neste lugar e o reconhece.

Um artista como etnógrafo é, em certa medida, um cartógrafo. É um desafio cartografar um espaço desconhecido por meio de uma etnografia sensível. Neste trabalho, José orienta o mergulho através da geografia dos afetos de Santo Antônio. Embarco nesta viagem guiada pelos olhos atentos dele, pois só um morador poderia estabelecer conexões entre certos pontos cartográficos. Com ele desenvolvi um olhar atento e comecei a observar cada árvore que via nos percursos que fizemos juntos. 


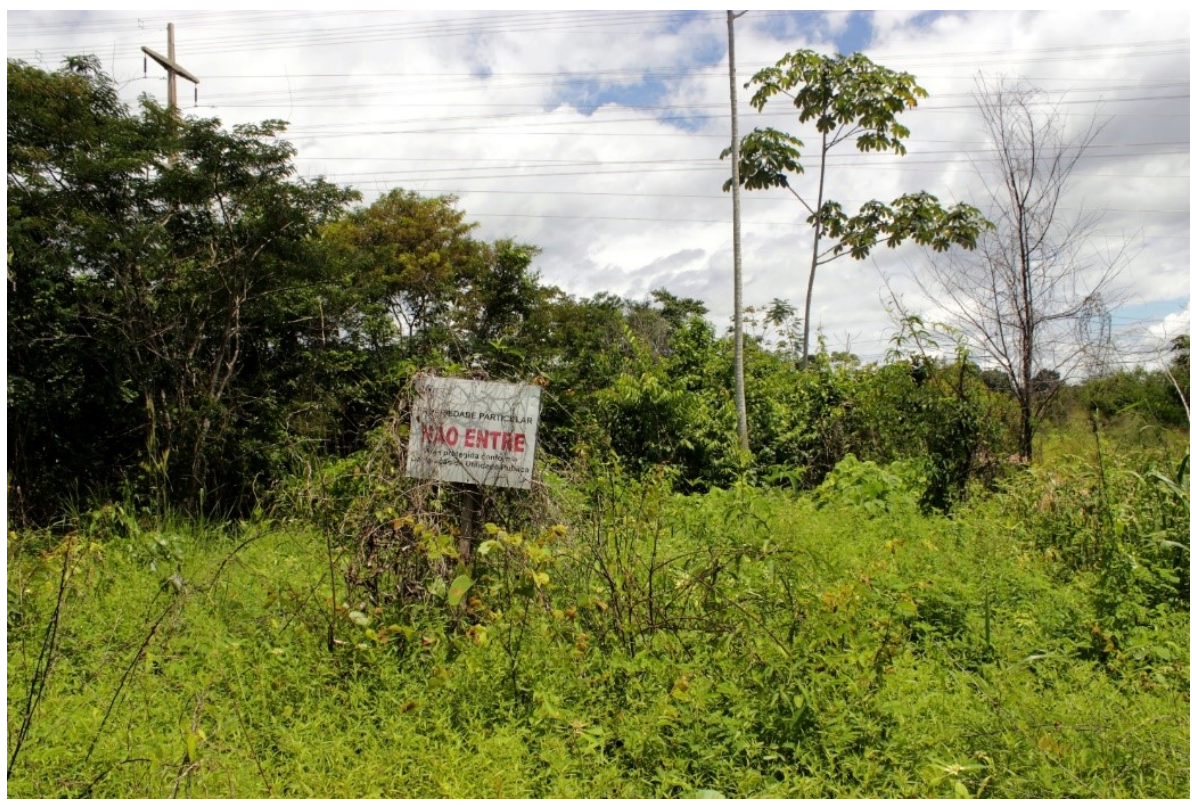

Fig. 3 - As placas demarcam a desterritorialização, 2016.

(Fonte: Acervo da autora.) 
Retornei mais uma vez à vila Santo Antônio em 2016. Caminhando pelas ruas que ainda existiam, de maneira simples, rápida e meio sem querer falar, José disse: "- Aqui era uma rua". Para ele, não importava muito observar como o mato e certas espécies de capins haviam crescido tanto ao ponto de não parecer mais que havia uma antiga rua ali. Para mim, era como contemplar uma ruína sem ruína, restavam somente as reminiscências do que um dia foi uma passagem, uma rua. A perda das relações estabelecidas foi sucumbida pela natureza em uma verdadeira simbiose sobre o lugar vivido.

A vegetação invade, resiste e reconfigura lugares como este, compondo assim novos pontos cartográficos e outros nãocartografáveis nas afetividades do vilarejo. Estes pontos se tornam evidentes quando demarcados através da memória individual de quem recorda, como fez José ao apontar a mangueira, a antiga rua e o "barracão", como ele mesmo disse, de Manoel.

Ao contrário das grandes construções da modernidade, a agrovila Santo Antônio foi construída como um lugar diferente de outras edificações modernas erguidas em pleno efervescente desenvolvimento econômico da região amazônica. O conceito de lugar aqui é compreendido em sua completude de relações que afluem nas trocas cotidianas através dos laços de vizinhança e de parentesco, ressaltando, assim, a "fala, a troca alusiva de algumas senhas, na convivência e na intimidade cúmplice dos locutores", como pontua Marc Augé (2002, p. 73). Oposto ao lugar, existem outros espaços destituídos de memória afetiva, são eles apenas espaços de transição, de passagem e não identitários, considerados como nãolugares (AUGÉ, 2002). Por este ponto de vista, a hidrelétrica de Belo Monte pode ser considerada como um não-lugar que inundou as memórias de Santo Antônio. 


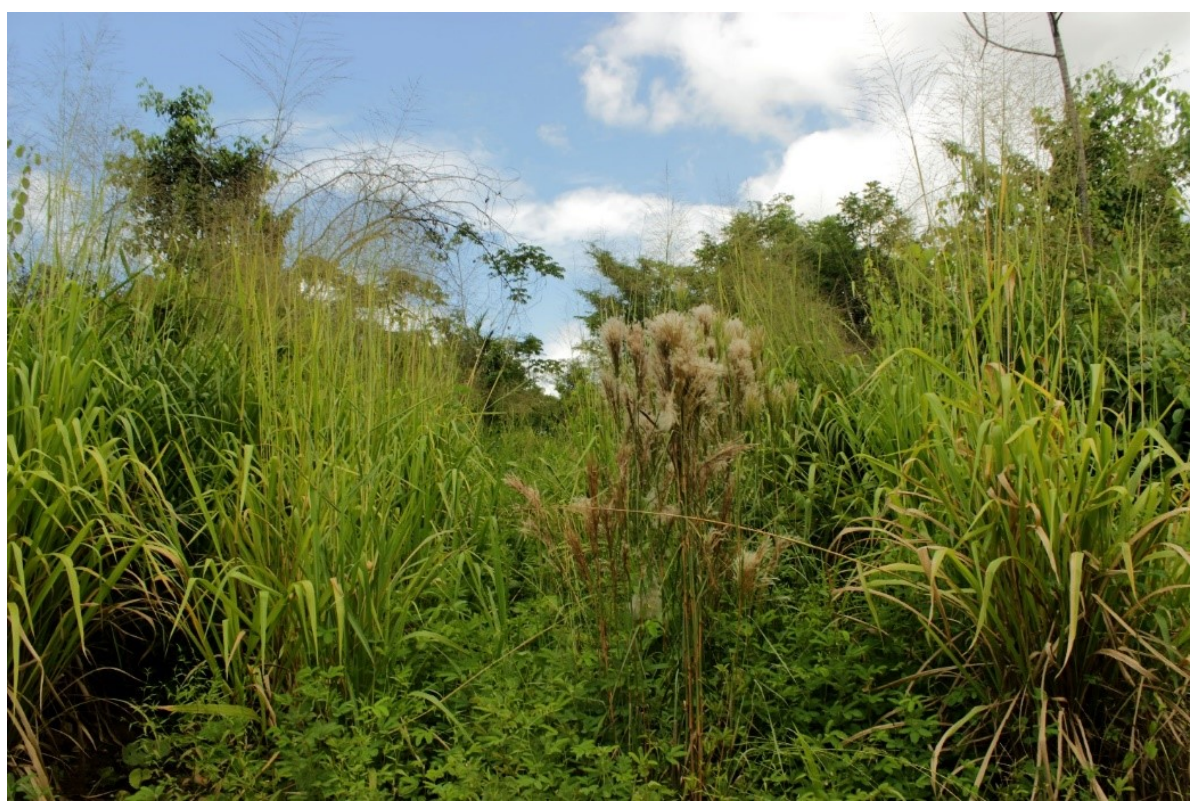

Fig. 4 - Aqui era uma rua, 2016.

(Fonte: Acervo da autora.) 
O trânsito intenso entre localidades e as imigrações sazonais são características fundamentais da região. Inicialmente, a agrovila foi agregando pessoas a partir de espaços comuns - dentre esses, a igreja, o campo de futebol e a sede como um espaço de lazer e organização política. A partir desses ambientes, as famílias foram solidificando o solo enquanto um lugar. Pedro disse que em 1973 foi criada a comunidade pelo desejo comum dos primeiros moradores, sem incentivo do poder municipal. As memórias de Pedro foram confrontadas com as de Antônio. Para Antônio, considerado o primeiro morador de Santo Antônio, a criação da agrovila acontece quando um técnico e uma assistente social da Emater decidem doar um terreno para abrigar um agrupamento maior de pessoas, antes espaIhadas, reunindo-as assim. Segundo ele, a estratégia usada pelos funcionários para atrair pessoas para as reuniões era distribuir leite em pó:

- Muita gente ia só para pegar o leite mesmo. Em uma dessas reuniões veio um técnico de agrovila, naquela época se chamava "prefeito de agrovila"; ele que doou aquele lote onde foi feito Santo Antônio. Ele falou: "Ao in- vés de vocês estarem se reunindo em coisas

alheias, vocês vão se reunir numa coisa de vo-

cês". Através disso começou Santo Antônio em 1973. (Entrevista gravada em áudio, Travessão do Pilão, Anapu, 2015)

A história da agrovila chega progressivamente ao seu final quando se iniciam as obras de escavações dos reservatórios de água de Belo Monte. É a história do desenvolvimento econômico que mais uma vez ocupa um lugar central na história da Amazônia, tornando a extinta agrovila gradualmente em um espaço de decadência, na medida em que os laços identitários, as relações cultivadas e a própria memória se esvaem abrindo margem ao esquecimento e à solidificação de poucas e significativas ruínas.

\section{Memórias inundadas}

"Quando eu cheguei? Porque assim, na cabeça da gente lá fora passa um filme na cabeça da gente. A gente vê os filmes que passa, inclusive eu cheguei a assistir filme lá no Espírito Santo em que a Transamazônica era asfalto, era asfaltada, sabe? Passava os caras quebrando as castanhas, eles fa- 
ziam um jirau de madeira e ficavam debaixo quebrando a castanha... Eu nunca vi isso aqui." José, Altamira, 2015.

Pedro conta orgulhoso que fundou a comunidade em 1973. Ele disse que só desocupou seu ponto comercial depois de quase três anos brigando judicialmente com a empresa responsável pela indenização. Desse momento, guarda na memória o período de intensas ameaças de despejo, quando mandaram um funcionário e um trator para derrubar seu estabelecimento. Ele não queria sair de onde estava por avaliar que a única saída para não enfrentar uma situação pior era resistir dentro de seu imóvel. Ele temia ser realocado em um Reassentamento Urbano Coletivo, como chamam os bairros planejados pela empreendedora de Belo Monte, onde as casas são padronizadas, todas de três quartos. Ele queria voltar à vida passada.

O primeiro morador da Transamazônica de Marabá à Altamira foi Pedro, como ele mesmo me disse: "não tinha outro, era só dentro da mata eu". Ele veio de Belém com 35 anos, "casado e fugido". Fugido porque quando era mais novo brigava bastante. É natural de Bujaru, distrito do município de São Domingos do Capim, nordeste paraense, onde acontece o famoso fenômeno natural, a Pororoca, no rio Capim. Quando chegou à região do Xingu, naquele tempo de barco até Vitória do Xingu, a Transamazônica ainda não havia sido inaugurada, por isso ressaltou o privilégio de assistir à cerimônia em que o Presidente Médici cortou a castanheira simbolizando a chegada do "progresso", em novembro de 1973. O "pau do presidente" é como as pessoas, em Altamira, chamam o memorial feito no local. O que na memória de Pedro aconteceu em 1973, os documentos históricos afirmam ter ocorrido em 1970.

Como comerciante, Pedro gostava de falar em números. Quando eu posicionei a câmera na mão e um gravador, ele prontamente se preparou para tecer denúncias sobre os abusos vividos por causa de Belo Monte. Assim, me explicou a situação judicial em que se encontrava por não ter aceitado a oferta de indenização de $R \$ 92.000,00$ (noventa e dois mil reais), valor dado a todos seus bens. Seu ponto comercial tinha 130 metros de frente por 100 metros de fundos, um 
simples jeito de falar de um lote de um pouco mais de um hectare. Nas promessas feitas no passado, ele receberia mais por todas as benfeitorias.

Devido ao fato de ter rejeitado a oferta de indenização, Pedro conseguiu receber uma "bolsa-aluguel" por pouco mais de um ano, o que já havia acabado quando eu o conheci. No auge da construção de Belo Monte, o aluguel do ponto comercial onde morava chegou a custar R\$ $2.500,00$ (dois mil e quinhentos reais) em virtude da localização, à beira da rodovia. O estabelecimento funcionava como bar e mercearia. Não havia um banheiro reservado para clientes e, para acessar o único que tinha, os clientes precisavam passar pela sala doméstica, pois não cabia um banheiro mais próximo e separado do espaço da casa. Sem "medir" palavras, Pedro fala: "o lazer que eles me deram foi ficar nesse chiqueiro".

Sem letramento, Pedro teve que lidar com uma justiça escrita com papel e caneta. Mesmo com as novas ameaças de despejo por causa das dívidas contraídas pela falta de pagamento de aluguel, Pedro foi enfático ao afirmar que naquele momento não queria só uma "casa de morada", como chamou, mas sim um ponto comercial semelhante ao que tinha, na beira da estrada, onde também pudesse ter uma casa de morada espaçosa e um quintal. Talvez Pedro não fosse o primeiro morador da Transamazônica, mas em suas andanças pela mata é possível não ter encontrado mais ninguém. Para chegar à cidade de Altamira, antes da Transamazônica, as pessoas andavam pela floresta fechada. De primeiro morador de um perímetro marcado pela rodovia ao último habitante da agrovila, ele conta que só saiu de Santo Antônio porque não teve mais para onde fugir.

Assim como outras pessoas impactadas por Belo Monte, Pedro se descobriu depressivo. Ou a depressão o descobriu. Não é difícil imaginar esses casos dado a expectativa criada em torno da obra, seguida de uma profunda decepção. Todos tiveram a esperança de ganhar uma boa indenização e conseguir se mudar para outro lugar com condições similares ou melhores, porém esta realidade foi para poucos, em especialmente para proprietários de fazenda e criadores de gado. Depois da saída da vila, ele começou a se 
tratar de depressão, mas interrompeu em seguida. Parou de tomar remédios porque, segundo ele, "não adiantava tomar e ficar da sala para a cozinha, da cozinha para a sala. Se for assim, era melhor esperar morrer logo".

Um ano depois da primeira entrevista com ele, o visitei novamente. Ele permanecia na agrovila $D^{\prime}$ Vinci, em outra casa, onde também mantinha um bar e uma mercearia. Naquela época, me disse se ver como uma pessoa agoniada, muito diferente do Pedro comerciante de Santo Antônio, antigo agricultor da região. Foi ele quem ensinou Leo, o baiano, a cultivar arroz. Se reconhecia como pescador e pescava nos momentos de lazer. Mesmo não querendo recordar, ele rememora:

\footnotetext{
Rapaz, eu não quero lembrar de nada de lá, porque do jeito que eu morava lá, que tinha a minha tranquilidade, eu tinha tudo, tinha 0 Xingu, praia boa, a minha canoa, os meus utensílios de pesca para eu ir pescar e fazer do meu lazer que eu vivia, para vir para um inferno desse... eu não quero lembrar de nada de lá. (Entrevista gravada em áudio, agrovila D’Vinci, 2016)
}

Considerações Finais

A história da pequena vila de Santo Antônio prossegue sendo excluída e eliminada da história do desenvolvimento da região. Narrá-la é um jeito de adiar seu esquecimento. É também uma singela homenagem a Maria, também antiga moradora, por me dizer temer o esquecimento de Santo Antônio. Ela me advertiu: em breve ninguém mais vai se lembrar que, por trás do estacionamento de caminhões de Belo Monte, havia uma comunidade.

A história de Santo Antônio nunca foi não escrita, mas falada, gesticulada, vivida. Não tive o objetivo de recompor toda sua história, pois busquei fios de memória que compõem mais uma história invisibilizada pela "modernidade" na Amazônia. Justifica-se com isso a investigação por meio da incessante busca por imagens presentes nas narrativas sobre o passado, uma vez que "há um visível que não produz imagem, há imagens que estão todas em palavras" (RANCIÈRE, 2012, p. 16). 


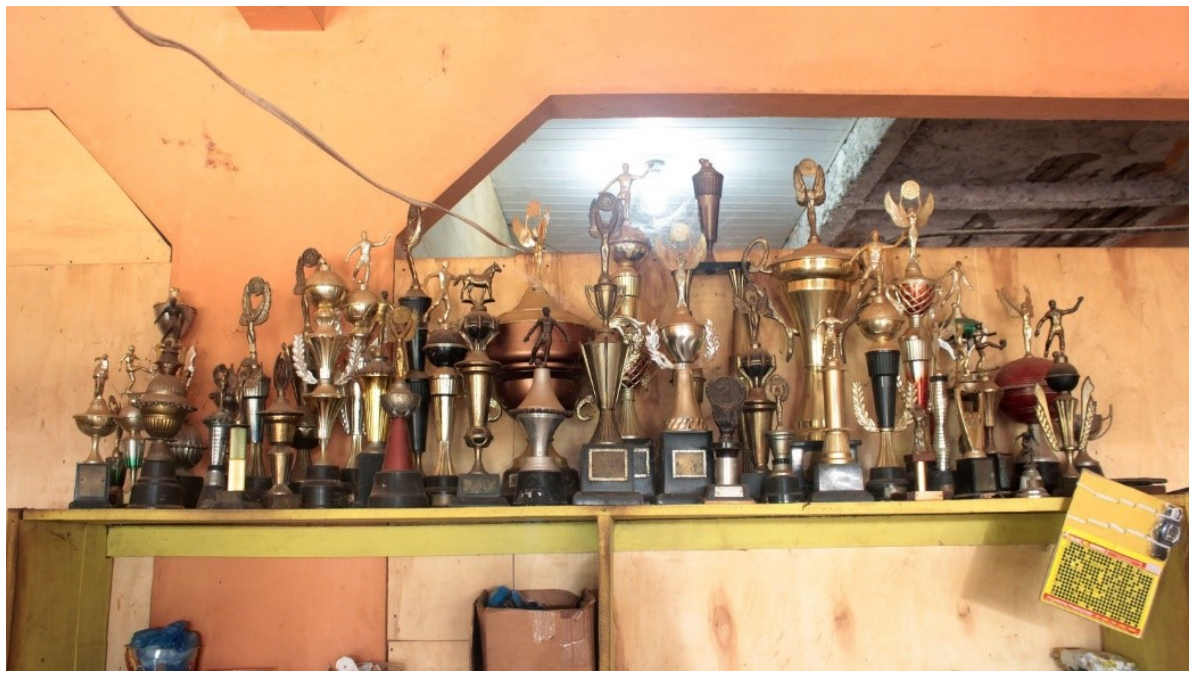

Fig. 5 - Os troféus dos campeonatos de futebol de Santo Antônio guardados por Pedro, 2015. (Fonte: Acervo da autora.) 
A agrovila como um lugar se determinou por meio da condição de convivência, das trocas e de organização social. Foi no encontro com o rio Xingu que José tirou seu sustento e sua alegria. Nas conversas e nos silêncios, ele me presenteou com suas imagens não-cartografáveis, suas memórias inundadas, imagens de um coração que adotou a Amazônia como um lugar afetivo. É nessa região que descobri uma infinidade de subjetividades cultivadas no aprendizado constante com o rio e com a natureza.

Investigações que priorizem os discursos silenciados têm suma importância para dar ênfase à outras histórias, ao saber local que habita as fissuras da história do desenvolvimento econômico nacional, dita como oficial e prevalecente na sociedade. Se pretendeu visibilizar parte das histórias e memórias coletivas de quem sofreu com os efeitos socioambientais provocados pela barragem do rio. Das famílias que visitei, em diferentes localidades, optei por não apresentar todas neste trabalho, fazendo um recorte de pesquisa para privilegiar os moradores antigos com quem tive mais contato. Eles acompanharam diversos processos na história da agrovila e são guardiões da memória da comunidade. Essas famílias, além de mais antigas, são compostas por matriarcas e patriarcas mais velhos, o que as diferenciam de outras famílias mais novas.

Ao conectar estudos de diferentes campos, como a Arte e a Antropologia, as análises apresentadas contribuem para ampliar as discussões sobre o estado da Arte e a função do artista - mesmo não sendo o foco do trabalho. Por fim, concluo me apropriando das palavras de Clifford Geertz (2014, p. 103): "estudar arte é explorar uma sensibilidade" e isto "é essencialmente uma formação coletiva". As incursões em campo me proporcionaram vivenciar, dentre outras coisas, a experiência de artista enquanto etnógrafa (FOSTER, 1996). 


\section{Notas}

${ }^{1}$ A Transamazônica faz parte do projeto geopolítico de integração nacional executado durante o Regime militar, na década de 1970 . Terceira maior rodovia do Brasil, com 4.223 quilômetros de comprimento, ligando Cabedelo, na Paraíba, à Lábrea, no Amazonas.

${ }^{2}$ Michael Pollak (1989, p. 4, grifo meu) escreve: “Ao privilegiar a análise dos excluídos, dos marginalizados e das minorias, a história oral ressaltou a importância de memórias subterrâneas que, como parte integrante das culturas minoritárias e dominadas, se opõem à 'Memória oficial', no caso a memória nacional". 0 conceito de memórias inundadas faz referência ao rio Xingu e a barragem, também evoca as memórias subterrâneas de Pollak, apresentadas no seu texto "Memória, Esquecimento, Silêncio".

${ }^{3}$ Todos os nomes citados neste artigo são fictícios com o fim de preservar a identidade dos entrevistados.

${ }^{4}$ Rodovia Transamazônica e rio Xingu.

${ }^{5}$ Em 2019, de volta ao campo de pesquisa, confirmo que as estruturas remanescentes da vila, assim como seu cemitério, continuam no mesmo local.

\section{Agradecimentos}

Agradeço, em especial, à Luana Peixe e à Janaína Torres, companheiras da primeira pesquisa de campo do qual este trabalho resulta. A leitura atenta do Professor Dr. Luizan Pinheiro enriqueceu este trabalho, por isso o agradeço imensamente. 0 presente trabaIho foi realizado com apoio da Coordenação de Aperfeiçoamento de Pessoal de Nível Superior Brasil (CAPES).

\section{Referências}

AUGÉ, Marc. Não-lugares: introdução a uma antropologia da supermodernidade. São Paulo: Papirus/Travessia do Século, 2002.

BOSI, Ecléa. Memória e sociedade: lembrança de velhos. 3 ed. São Paulo: Companhia das Letras, 1994.

DALCOL, Francisco. Ruínas da modernidade e utopias fracassadas: a fotografia de Romy Pocztaruk. Revista-Valise, Porto Alegre, ano 5, v. 5, n. 10, dez. 2015.

DELEUZE, Gilles; GUATTARI, Félix. Mil platôs: capitalismo e esquizofrenia. Rio de Janeiro: Ed. 34, 1995. v. 1. grafo. In: The return of the real: the avant-gard at the end of the century. Tradução Alexandre Sá. London: The MIT Press, 1996.

GEERTZ, Clifford. O saber local: novos ensaios em antropologia interpretativa. 14. ed. Petrópolis, RJ: Vozes, 2014.

LATOUR, Bruno. Jamais fomos modernos. 3. ed. São Paulo: Editora 34, 2013.

NORA, P. Entre memória e história: a problemática dos lugares. Projeto História, n. 10, 1993. 
POLLAK, Michael. Memória, esquecimento, silêncio. Estudos Históricos, Rio de Janeiro, v. 2, n.3, 1989.

RANCIÈRE, Jacques. O destino das imagens. Rio de Janeiro: Contraponto, 2012.

REIS, Camila do S. Aranha dos. Território da perda: memórias inundadas e fotografia na Amazônia pós Belo Monte. 2016. 148 f. Dissertação (Mestrado em Arte e Cultura Contemporânea) - Instituto de Artes, Universidade do Estado do Rio de Janeiro, Rio de Janeiro, 2016. 